\title{
Expectations and Experiences of Peacebuilding in Sierra Leone: Parallel Peacebuilding Processes and Compound Friction
}

\author{
Gearoid Millar
}

[7500]

Keywords: transitional justice, truth commission, friction, post-war, Sierra Leone, peacebuilding, local experience

This article investigates local experiences of the Truth and Reconciliation Commission for Sierra Leone and explains how these experiences were influenced by the parallel administration of many peacebuilding processes. Using qualitative data it shows how the goals and procedures of these various processes overlapped and interacted in the imaginations of local people, generated unpredicted expectations, and eventually led to negative experiences of the commission's work. I describe how Tsing's idea of 'friction' can helpfully explain local experiences of peacebuilding and the new concept of 'compound friction' is introduced as a tool for understanding the local impacts of parallel peacebuilding processes.

A great amount of recent peacebuilding literature examines the relationship between theory, practice, and experiences of peacebuilding interventions. Much of this literature argues that many peacebuilding practices are disconnected from local postwar needs and indigenous approaches. ${ }^{1}$ For example, peacebuilding approaches that center on liberal economic and democratic principles - what has come to be known as the liberal peace' - have been widely criticized. ${ }^{2}$ This is true also of peacebuilding approaches that attempt to provide transitional justice and intergroup reconciliation, including truth commissions. ${ }^{3}$ In many ways established theory and the currently popular approaches to peacebuilding have been under a sustained assault as detractors have claimed that they are overly top-down, elite centered, and externally driven. This paper aims not to 
add to this critical literature, but to provide a potential explanation for some of the negative local experiences reported regarding peacebuilding interventions and to, at the minimum, provide a new perspective on the problem.

Using qualitative data regarding local experiences of the Truth and Reconciliation Commission (TRC) collected during ten months of fieldwork in northern Sierra Leone, this paper describes the manner in which local people experience parallel peacebuilding processes - interventions applied simultaneously within the postwar setting - as interrelated, interacting, and sometimes confused. In the situation examined here local people re-imagined the goals and processes of the TRC in interaction with those of the various parallel peacebuilding processes, imagining connections and relationships between them and eventually undermining the coherence of the TRC in ways unpredicted by the international planners and administrators. What the data demonstrates is that international peacebuilding, and particularly complex peacebuilding efforts characterized by the parallel administration of multiple processes, is inherently generative of unexpected and potentially disruptive experiences among local people.

In response, I turn to the concept of 'friction' put forth by Anna Lowenhaupt Tsing. ${ }^{4}$ While Rosalind Shaw has already exhibited how this concept can assist peacebuilding scholars and practitioners in understanding interactions between the international and local in Sierra Leone,${ }^{5}$ I show how the concept can be expanded to understand 'compound frictions' wherein a diversity of international peacebuilding interventions - each embodying different and even competing "universal" norms and paradigms - interact with one another in the minds and imaginations of local audiences to produce unpredictable expectations and experiences. While Tsing's friction recognizes the interaction between international and local to be active and unpredictable, I argue there that 'compound friction' allows us to focus attention on the dynamic interaction on the ground between multiple parallel interventions within and among local actors. This paper, therefore, illustrates how the administration of parallel peacebuilding processes by the international community adds additional complexity to already "awkward engagements." 6

The rest of this paper is divided into five parts. The first part briefly describes the civil war in Sierra Leone, the practices of the TRC, the goals it hoped to attain, and the 
research methodology I used to investigate the local experiences of the process in Makeni, a town in the rural north of the country. Part two presents my data and describes the problems encountered by the TRC. This section focuses specifically on how local people conflated in their own minds the processes of the various peacebuilding projects and how this affected local expectations and experiences of the TRC. Part three returns to Tsing's notion of friction and describes the generative nature of interaction between international universals and local particulars, while part four proceeds to expand this theory and describe the concept of 'compound friction,' or the interaction between international interventions competing in their travels to transport among local settings different "universal" paradigms and ideas. The conclusion argues that peacebuilding, as both a practical and scholarly endeavor, must begin to recognize the true implications of complex peacebuilding projects in postwar settings and makes a number of simple recommendations towards this end.

\section{War, Truth Telling, and Evaluation of Experience in Sierra Leone}

For 11 years between the spring of 1991 and early 2002 Sierra Leone was the site of one of the most violent and confused conflicts in recent history. The war started with a small incursion from neighboring Liberia. However, as this small group, labeling itself the Revolutionary United Front (RUF), attracted dissatisfied and disaffected portions of the population of Sierra Leone its numbers and strength quickly grew. Within just one year the RUF managed to accomplish its stated primary objective, the overthrow of the All People's Congress (APC) government, which had at that point been in power for some 24 years. However, instead of putting down their arms and joining the government in power, the new government and the RUF continued to fight, the conflict spiraled out of control, and violence became a common occurrence throughout the country for the next ten years.

Over this period a number of different armed groups committed various atrocities throughout the country. Children were regularly recruited and indoctrinated into many of them, ${ }^{7}$ women and girls were captured and taken as 'bush wives' and often subjected to rape and forced labor, ${ }^{8}$ and the amputation of hands, feet, arms and legs became a 
common event. ${ }^{9}$ The war degraded into a series of failed peace accords and coups, with the RUF at one point joining with former Sierra Leonean Army (SLA) troops to form the Armed Forces Revolutionary Council (AFRC). This unfortunate period brought some of the worst atrocities of the war to Freetown itself, with one particularly violent period being aptly named 'operation no living thing'. ${ }^{10}$

It was for the purposes of responding to such atrocities that the international community established the TRC at the end of the war with the primary purpose of discovering truth in order to catalyze reconciliation; to provide psychological healing, catharsis and restorative justice. The TRC attempted to do this through public education and mass media based sensitization, statement taking, public hearings, and the creation of a database of wartime violence. ${ }^{11}$ However, following the South African model, the linchpin of its interaction with the general Sierra Leonean public were the public hearings. ${ }^{12}$ Conducted in the headquarter towns of each of the countries rural districts as well as in Freetown, these hearings were public performances of victim, witness, and perpetrator stories, in front of audiences of local people, key stakeholders, and the media in town halls and community centers throughout the country. This particular process is one example of what has become a primary vehicle of intergroup reconciliation in postwar settings over the past thirty years.

TRCs are often considered to be a compromise form of justice, situated somewhere between the close examination of evidence foundational to retributive justice and the failure or refusal to examine the past which characterizes impunity. ${ }^{13}$ They allow the identification of the guilty and the innocent, the victim and the perpetrator, without the new pain of punishment, and this is theorized to create restorative justice and healing. Although the initial bodies that were later be defined as truth commissions generally only collected witness, victim, and perpetrator stories for the purpose of report writing - to form an official history of violations during war or authoritarian rule - in the wake of the defeat of Apartheid in South Africa, an alternative path was chosen. In this new model stories became public testimonies thought to catalyze national healing, intergroup forgiveness, and reconciliation. In this way the public hearings process, the performance of truth telling in front of live audiences in 
towns throughout the country, was itself theorized to create what Nadler and Schnabel have called 'socioemotional' reconciliation. ${ }^{14}$

This South African approach became a touchstone and model for all future commissions, ${ }^{15}$ including the Sierra Leonean TRC, which adopted the idea of public hearings and itself claimed that such public performances of truth telling would 'cater to the needs of the victims' and promote 'social harmony and reconciliation'. ${ }^{16}$ These public hearings were not necessary for collecting information regarding the conflict. The stories presented had already been recorded by the TRC staff during the statement taking phase of the commission's work. Instead, the hearings can only be understood as an attempt to initiate psychological healing and reconciliation through a cycle of apology, acknowledgement, forgiveness and assurance, as described by various conflict resolution theorists. ${ }^{17}$ However, anthropological work studying the effects of these hearings among local audiences described the TRC not as cathartic, but as disconnected and culturally inappropriate. ${ }^{18}$

It was to explore the inconsistencies between transitional justice theory and these more locally grounded evaluations that I spent ten months in northern Sierra Leone conducting an ethnographic evaluation of the local understandings, perceptions, and experiences of the TRC's work in Makeni - a semi-rural town in northern Sierra Leone - from August 2008 to July 2009. I spent the first three months of my time in Makeni volunteering with a local non-government organization (NGO) focusing on child health issues, learning Krio, and getting acquainted with the town. Throughout this time I also volunteered with a number of different organizations to become knowledgeable regarding the local situation from different perspectives. After three months I hired a research assistant and translator and conducted 62 semi-structured interviews among various groups. Thirty interviews were conducted among local people who had attended the TRC's public hearings and were sampled through snowball sampling, 12 interviews were conducted with local elites such as business leaders, the Paramount Chief, the District Chief Imam, the Mayor, the Bishop, etc., and 20 interviews were conducted with town residents, sampled randomly from a database of all addresses in Makeni and interviewing the first willing adult at each house. 
In these interviews I tried to determine what local people had understood about the TRC process, how they had been sensitized to it and how much they had been engaged by the project. I tried to determine how they had experienced the process of the hearings, if it had been a good thing or a bad thing, and how their family, friends, and community had reacted to the hearings process. For those who had not attended, I tried to determine why they had chosen not to and if they felt they had missed an opportunity by not attending. Throughout, I avoided using terms such as reconciliation, healing, or justice, instead asking if the TRC had done what people expected or needed it to do, or if it had helped them to recover from the war. From these interviews a detailed picture of local experiences of the TRC emerged, but it was not what scholars of transitional justice or reconciliation predict.

\section{Local Expectations, Experiences, and Parallel Peacebuilding Processes}

If you talk only to the local educated English speaking elites in Makeni, or as one local man described them, those who 'hold the town,' you might come to believe that both the goals and processes of the TRC were clearly communicated to the local audience. As the Mayor said to me, the TRC went 'to every last village.' But, confirming findings from earlier studies, ${ }^{19}$ the situation proved not so simple. Over the course of my interviews around Makeni I found that the supposed sensitization messages of the TRC, what it intended to do and how it intended to do it, was unevenly understood and that many non-elites either did not or could not distinguish the processes and procedures of the TRC from the work of other organizations active in the postwar setting. This was particularly true of the Special Court for Sierra Leone (SCSL) and the demobilization, disarmament, and rehabilitation (DDR) program for former combatants. ${ }^{20}$ As the processes of the TRC were conflated with those of other peacebuilding interventions many of my interviewees had misconceptions which raised expectations about what it would or could do for them. As a result, local's overall experience of the process were heavily affected by the operation of these parallel peacebuilding processes.

In Sierra Leone there was a large radio campaign that was supposed to inform the population about the goals and processes of the TRC. Indeed, almost everyone with 
whom I talked said that they had heard programs on the radio that mentioned the TRC, and from this radio campaign some sensitization was achieved. The general idea of reconciliation between people seems to have been understood and even appreciated. Brima, a 25 year old farmer, told me that they had 'brought the TRC because we were having war in our country, so that they will bring those that were in the bush and we the civilians to talk to us, so that we have peace with them.' Lansana, 30 years old, said that the 'the reason why they decided to come with the TRC is to make people forgive and forget.' Similarly Yamboi, a 30 year old salesman, said that 'the TRC means peace ... during that time they were trying to bring people together, they were trying to explain the message for all that has happened. Let us forgive and forget.'

Each of these quotes describes, broadly, the actual mission of the TRC, and in this way we can see the partial success of the radio sensitization campaign. However, providing this quite cursory understanding of the goals of the TRC - peace, bringing people together, forgiving and forgetting - does not really provide any understanding of the process of the TRC, and it was the process that was confused with various other peacebuilding interventions. Yeabu was a 30 year old food seller, a woman who had left Makeni when she was younger but had returned during the war. When Yeabu was asked what she had heard as the key message of the TRC's radio sensitization campaign she responded:

What they were saying is that, they said they had cut the hands of people and now they are not having any help, others have died, others are not able to help their children to go to school and not giving them half help. The people are suffering.

This she interpreted as the key message of the TRC's radio programs. Not anything about how the TRC would work or what it would do. The radio messages were supposed to explain what locals should expect from the TRC, but these important points were not well communicated and the result, among many, was a great amount of confusion between the TRC and the various other post-war processes that were administered after the war. For example, as was reported also by Schabas and by Shaw, ${ }^{21}$ many non-elite locals confused the operations of the TRC with those of the SCSL. 
Kumba, a 37 year old woman working as a trader, who had attended the TRC, had seen her cousin shot during the war in Lunsar, where, she told us, the rebels had also burned her Aunt's house. When asked what she had heard about the TRC on the radio she responded that the TRC had come 'to judge those that were involved in the war.' Similarly, Adama, a 29 year old woman also working as a trader, said that 'when they called on those that did bad things ... they took them to court.' Even Abdul, a young police officer, argued that the TRC was 'to try those, that those that committed the greatest responsibility, for them to be brought to book, so that they can answer exactly.' This role, the trial of those bearing the 'greatest responsibility,' was the mandate of the SCSL, not the TRC. In this way, the messages non-elite locals understood from the sensitization campaign were confused and conflated with the messages being communicated regarding the SCSL, which operated parallel to the TRC.

Schabas considers this a potential success of the TRC's sensitization campaign, in that it proves, he says, that locals had knowledge of the existence of both bodies. ${ }^{22}$ But I would argue the opposite. I would say it shows that local non-elites confused the two processes. Horovitz suggests that when Truth Commissions and courts function side by side 'advance planning should include a comprehensive sensitization program prior to the creation of the mechanisms to educate the public on their respective roles'. ${ }^{23}$ In an ideal world, this is how it would work. However, such confidence in sensitization campaigns in desperately poor countries among largely illiterate populations is naïve. When these two parallel peacebuilding processes interacted with the local communities they produced not clear impressions of their respective mandates, goals and procedures, but misunderstanding and a conflation of purposes. The two streams of information were intertwined and re-imagined by local people; absorbed into an unpredicted conception of both the TRC and the SCSL; one that the planners of both had failed to expect and which produced among local people unpredictable expectations. However, it was not only these two transitional justice institutions that were confused among the population.

Other local people confused the work carried out by the TRC with that of international NGOs; confusing what was provided to them by Care, Plan, UNICEF, 
Doctors without Borders, or other NGOs, with what was done by the TRC. Kondeh, a young man I met at Panlap amputee village, was a good example of this. Kondeh had been stabbed in the stomach during the war and now had yards of plastic tubing in place of parts of his intestines. He had to eat a very particular amount of food each day to avoid a debilitating pain resulting from a blockage or a collapse of his plastic insides. Only 19 at the time of the interview in late 2008 (12 or 13 at the end of the war), Kondeh saw no difference between the organization that provided him with medical services and food and the TRC. As he said when asked if the TRC had accomplished its goals:

Well for me at least, TRC, they tried. For me they did well. Because if I am living now it was for them as my condition was not good. I went on surgery for about four times, at the government hospital in Freetown, I went there three times. After that a doctor was brought from overseas and was able to do it successfully, because everybody thought I would die.

It is quite clear that the TRC did not provide Kondeh, or anyone else, with medical care, but throughout our interview he conflated the work of some international relief agency or NGO with that of the TRC.

Amadu, a local area chief on the south side of Makeni, was also unsure about what work was completed by the TRC and what was the work of NGOs. When we asked him what things the TRC had done to help create peace, Amadu said that they 'saw a lot were built for, we just don't know if it was the TRC that did that.' Hawa said she did remember the TRC, and she had appreciated its work. However, when asked to describe what they had done she described the work of a local NGO that conducted family mediation. According to Hawa, the best work that the TRC did was 'what they have done for this, my sister and her husband. I have learnt that they have done something for me that I will never forget. Their marriage was almost coming to an end.' Hawa thought the TRC had conducted domestic mediation processes and helped her sister resolve her marital problems.

These are simple examples of the great amount of misunderstanding among non-elites between what other postwar processes did and what the TRC accomplished. The radio sensitization campaign appears to have been rather successful at informing people that the TRC was coming, or that it would assist in bringing peace. However, it 
was not at all successful in communicating to people the position of the TRC relative to other post-war actors or the specific processes it would carry out, as distinct from these other projects. In turn, because many people were confused about what the TRC would do they reconfigured the many messages they were hearing to create their own interpretations; leading to unfounded expectations. Those who confused the TRC with the SCSL believed it would put people in jail while those who confused it with NGOs felt it should build houses or provide medical care.

Similarly, and perhaps most problematically, a number of people interpreted the functions of the TRC through a perspective clouded or colored by the experience of the DDR program. These local people believed that the TRC would or should provide 'packages', as had been received by the ex-combatants who participated in DDR. This was most poignantly voiced my Momadu, a 72 year old amputee at Panlap amputee camp who stated that:

The TRC, what they put in front was they were to give the former combatants packages, and they said after that they are going to consider us, the victims. Our consideration is still to come forth, since we don't hold guns and our business looks to be delayed. Most of our brothers have died. So but now some of us that are still living we don't know if we will have the opportunity for that because even me sitting here I am not well.

Similarly, Michael, the leader of one of two Polio victims groups in Makeni, felt that the TRC was a 'provocation,' because there was 'no packet for people that suffered' and nothing for those who told their stories. I learned, over my time in Makeni, that the word 'packet' is indicative of an implicit comparison between the TRC's benefits vis-à-vis victims, and the DDR program's benefits vis-à-vis perpetrators. In the comparison, and sometimes confusion, between the two processes, the manner in which they became interrelated in the re-imagined conceptions of local non-elites, the DDR program had itself set expectations for the TRC. In turn, that reconfiguration, with all of the associated expectations, greatly impacted the evaluation of the TRC among local non-elites.

Even local elites - who had a much better idea of the TRC's process and a more positive evaluation of the TRC overall ${ }^{24}$ - were quite vocal in their condemnation of the 
TRC for not following through on this expectation among the non-elites and the direct victims of the violence. They voiced anger at the TRC for raising the expectations of non-elites and then failing to deliver. Mustapha, a graduate of the local Catholic College, stated:

Promises were made fitfully, to these people that ... after the TRC hearing provisions are going to be made especially to those who were amputated, those who were raped. I, I was actually convinced that indeed the TRC came actually to mend fences.

Similarly Abdullah, a drugstore owner, who, when asked if people are waiting to this day for reparations, said:

YES! They are expecting something, especially when the international community just focused to the perpetrators, encouraging them ... But the victims now, who suffered the brunt of the war, have been neglected.

Sally, a former staff member at the Center for Democracy and Human Rights (CDHR), the local NGO which assisted in the administration of the TRC hearings in Makeni, stated:

I see them, some of them who talk, there was supposed to be a reparation packet, up to now they are waiting for it. Like the amputees at Panlap, this is a crime.

In each of these quotes, we see the speaker, an educated English speaking local elite, describe the situation of the non-elites, the local-locals as Richmond has called them, ${ }^{25}$ as expecting something and as feeling aggrieved at having not received it. These speakers highlight that the expectations for the TRC among local non-elites were set by the processes of the DDR program, which provided the perpetrators of the violence with resources. As the TRC stated in its sensitization campaign that it was coming to help the victims and to bring peace, this was interpreted or re-imagined, in the local context, that this would be the same form of help that had already been given to the perpetrators; packets including money, skills training, and tools to start a new job. The international community had given packets to those who 'had done the bad', so because it failed to do the same for victims it was seen, as one young woman named Hanna claimed, as coming 'to add pepper in my wound.' 


\section{Friction and International Intervention}

As was noted in the introduction, a great amount of recent literature has been wrestling with the divergence between theory, practice, and experience in the field of peacebuilding. As in the case of Sierra Leone, the theorized results of peacebuilding projects do not always emerge when interventions are applied in local settings. Instead, complexities abound at the sites where the international and the local interact. Intervention is rarely predictable. In response to similar dynamics in a different field, Anna Lowenhaupt Tsing introduced the concept of 'friction' as a means to understand the dynamic processes of "global interconnection." ${ }^{26}$ This concept allows us to study the movement of universalizing ideas from place to place in interaction with individual agents in particular local contexts who re-imagine and re-interpret them, and, in so doing, make them something new in their activation within that unique setting. In this way, Tsing argues that local "cultures are continually co-produced" through the "awkward, unequal, unstable, and creative qualities of interconnection across difference." ${ }^{27}$

A central analogy for Tsing is that of a tire on a road, wherein it is the interaction of the two that produces movement and change. Without the friction between the two there would be no progress. However, at the same time, as universalizing ideas travel this generative friction is a source of heat, of tension, of debate, and of conflict. A paradigm or idea in one place may produce freedom, liberty, or justice for individuals or groups, but once it is seen as a universal and is transported to another setting it may have unexpected consequences. Tsing argues that this is because "concepts are transformed in translation" ${ }^{28}$ and the imposition of a paradigm in a new setting can produce unpredictable results.

One way that this happens, she argues, is through "travelling packages;" concepts or universalizing ideas that "travel when they are translated in such a way as to form a significant intervention in a local scene." 29 Such interventions are bundles of principles and ideals, wrapped up in practices and allegories, transmitting norms of behavior and thought from one place to another. However, in crossing borders and 
interacting with new localities and differently socialized and acculturated individuals these packages are translated "to become interventions in new scenes where they gather local meanings and find their place as distinctive political interventions." ${ }^{30}$ In this way, such interventions must be seen as unpredictable and potentially destabilizing, but also as productive, while activated and incorporated only through local agency and autonomy. Within the idea of friction local actors are recognized as creative actors interacting, re-imagining, or re-structuring the universalizing ideas and practices intervening in their local setting.

In the case of Sierra Leone, Rosalind Shaw has already described the particular interactions between the TRC and local processes of memory and "arts of forgetting," 31 describing these interactions as "frictional." 32 Shaw clearly explains how the TRC embodied the "hegemonic, historically constituted Western memory discourse" in an "internationally compelling ... model that linked the painful verbalization of memory with personal empowerment and national redemption" which, with its apparent success in South Africa, created "a new paradigm of transitional justice". ${ }^{33}$ This traveling package of an international norm, a "universalizing idea" in Tsing's terminology, interacted with the locally salient and dominant processes of memory and created something new, the friction between the two was, as Shaw describes, "in some ways productive, creating new forms of remembering and forgetting. ${ }^{34}$ While local people did not respond to the TRC in the manner expected or predicted by those who planned the TRC, they integrated "their testimony into prevailing understandings of healing and forgetting." ${ }^{35}$ In this way, Shaw shows, the interaction between the international (the TRC) and the local (traditional processes of social recovery), exemplified the pattern identified by Tsing.

However, I want to build on this and argue that friction, conceived as occurring between this single intervention - this one traveling package - and local processes is only a part of the story. In the case of Sierra Leone, I would argue, the turbulent interaction between the TRC and local processes of memory and recovery was aggravated further by the parallel operation of scores of interventions, each embodying a particular conception or paradigm of postwar needs, a different 'universalizing idea.' As articulated by Shaw, the TRC did embody an internationally accepted paradigm of postwar needs regarding proper postwar memorial and reconciliation - so well 
articulated in Nadler and Shnable's "needs-based model of reconciliation," ${ }^{36}$ and can be seen as a traveling package. But the SCSL, the DDR program, and the myriad NGO processes that intervened in the postwar setting of Sierra Leone must also be seen as traveling packages transporting competing universalizing ideas. In this complicated environment peacebuilding interventions overlapped and interconnected in the minds and imaginations of local populations, producing not a friction between one traveling package and a local setting, but a compound friction between that local setting and a number of parallel peacebuilding projects.

\section{Parallel Peacebuilding Processes and Compound Friction}

Just as the TRC can be seen as a traveling package embodying a universalizing paradigm of transitional justice, so the DDR program can be seen as embodying a security based conception of postwar needs, where peacebuilding requires the demobilization, disarmament, and reintegration of troops. ${ }^{37}$ In this paradigm the purpose of DDR is to ensure future peace by disarming combatants in order to take away the means to violence and "ensuring security on the ground by providing effective policing." ${ }^{38}$ In addition, the reintegration of ex-combatants is seen as necessary to avoid future returns to violence ${ }^{39}$ and as such, in the case of Sierra Leone, ex-combatants who registered for DDR were provided with $\$ 150$, six months of skills training, and in some cases a set of tools required to begin working in that career field. ${ }^{40}$ The DDR program in Sierra Leone was, like the TRC, an embodiment of a particular international conception of peacebuilding best practice, being implemented in a local context and interacting in unexpected ways with the local community. It embodied, however, a very different universalizing idea than that embodied by the TRC.

Similarly, the SCSL embodies an international paradigm and represents another traveling package. Unlike truth commissions, which are understood to embody restorative conceptions of justice and to create peace by promoting intergroup reconciliation, criminal tribunals such as the SCSL are embodiments of retributive justice. Such bodies are rooted in paradigms aimed at incapacitation and deterrence, or at separating the perpetrators from the general population and stopping repetitions of 
similar atrocities in the future. ${ }^{41}$ This paradigm assumes that by holding individuals accountable for their crimes, by defeating an air of impunity, such tribunals will deter others from committing the same crimes in the future. ${ }^{42}$ As Diane Orentlicher argues: "[i]f the international community is to play an effective role in breaking cycles of impunity, it must do what it can to create a greater space for accountability." ${ }^{43}$ This is what these tribunals attempt to do, ensure accountability. Such a concept of justice supports the notion that individual punishment will deter crimes and is based on a complex of ideas which build to the conclusion that justice is served if the individuals you define to be the most responsible for atrocities are punished, thus avoiding the repetition of those atrocities. And, in this tradition, as noted above, the SCSL was responsible only for punishing those persons "who bear the greatest responsibility". ${ }^{44}$ The SCSL also was an embodiment of a particular international conception of right practice, being implemented in a local context and interacting in unexpected ways with the local community. But again, this is a universalizing idea quite unlike that embodied by the TRC.

And, of course, the work of NGOs too embodies a particular heuristic or paradigm of postwar needs. Throughout the world today a diverse array of NGOs provide food, healthcare, housing, education, livelihoods training, good governance programming, and many other services in transitional periods after violent conflict. As has been well articulated by scholars of international development, such institutions are embodiments of Western conceptions of development itself, transporting across the globe a particular conception of progress. Tsing identifies NGOs as involved in the internationalization of Indonesian environmentalism in her initial work on friction, ${ }^{45}$ while scholars such as Easterly ${ }^{46}$ and Duffield ${ }^{47}$ argue that NGOs are agents of a particular post-WWII paradigm of human progress. Of course, NGOs come in all shapes and sizes and attempt to tackle many different forms of social problems and concerns. But few question that NGOs are today central actors within what Lipschutz called the "global civil society" ${ }^{48}$ which communicate international ideas and conceptions of the "needs, interests, and values of people at large." ${ }^{49}$ As such, NGOs too embody particular universalizing ideas. 
As so we can see that, just as the TRC was a traveling package transporting a particular paradigm of transitional justice to a unique local setting in Sierra Leone - as identified correctly by Shaw - so the SCSL, the DDR program, and the various NGOs too were embodiments of particular paradigms, international universalizing ideas. But the idea of friction allows us only to study and imagine the interaction between individual traveling packages and local actors; isolating the particular awkward engagements between one international intervention and local agents from other ongoing influences. Within the field of peacebuilding, as shown above, the situation is far more dynamic and requires a way to conceptualize the interaction between local agents and multiple ongoing interventions. This can be achieved if we see the potential for interventions not only to interact with local settings and local agents in an isolated fashion, but to interact, within the imaginations of local agents, with each other; if we recognize the operation fo compound frictions. This is an important switch because the TRC, SCSL, DDR and NGOs are in many ways embodiments of competing paradigms and universalizing ideas, and yet they were clearly co-culpable in the generation of local experiences of each other.

The idea of compound friction, therefore, allows us to see how the goals and processes of parallel peacebuilding processes are intertwined with each other within the minds and imaginations of local individuals who, for their part, take this information and create of it what they will within their own context. This expansion of Tsing's friction serves as a window into this complicated dynamic in Sierra Leone, but such complicated interrelations between peacebuilding processes is not unique to the case of Sierra Leone. Indeed, all postwar environments today play host to similar numbers of parallel peacebuilding projects and require, therefore, that scholars and practitioners have some way to understand such complex dynamics. Compound friction provides that analytic tool.

\section{Conclusion}

One of the greatest challenges for peacebuilding scholars and practitioners today is to understand the interaction between the international and the local. This is paramount if 
peacebuilding interventions are to have any meaning to local people and if international interventions are to build peace. The data presented in this paper shows that any such understanding must take into account not only the frictions between peacebuilding interventions and agents in the local setting, but the interaction of many parallel peacebuilding processes administered in postwar settings within the minds and imaginations of those agents in a process of compound friction. If we do not understand how peacebuilding interventions are understood and experienced by local people when they are administered side by side, we have no chance of understanding experience of modern complex peacebuilding as a whole.

Based on this need I make a number of general recommendations for future peacebuilding practice and scholarship. First, practitioners must recognize the limits of sensitization campaigns regarding the mandates, goals, processes and benefits for local people of interventions within settings characterized by the administration of many parallel peacebuilding processes. Much more effort must go into any sensitization in such settings and, if sufficient funding and time cannot be provided for sensitization, then the viability of any such interventions should be called into question. Second, no practitioners should assume that the goals and processes of their intervention are understood within such complex peacebuilding contexts simply because they have conducted a sensitization campaign. Much more time and effort must be spent evaluating local understandings of peacebuilding interventions before, during, and after such interventions. This may be the only way to avoid the kinds of misunderstandings and negative experiences described in the data presented above.

Third, more peacebuilding scholars must conduct qualitative studies of local understandings of peacebuilding processes - specifically among local non-elites - prior to, during, and after they are administered. Future research must explore further the compound frictions within complex peacebuilding contexts and study more fully both how parallel peacebuilding processes are conflated in local settings and how, or even if, this can be avoided. Comparative case studies across countries will be important in any future research agenda. And finally, scholars of transitional justice, security sector reform, reconciliation, democratization, memory, economic restructuring, psychological trauma, and the many other fields involved today in peacebuilding interventions, must 
cooperate more regularly to understand how their proposed processes affect locals on the ground. Future research into compound frictions in peacebuilding contexts requires cooperation across the disciplines studying the interventions that embody the many 'universalizing ideas' of peacebuilding.

\section{Acknowledgements}

I thank the anonymous reviewer and Dr. Willemijn Verkoren, Director of the Center for International Conflict Analysis and Management at Radboud University Nijmegen, for very useful and constructive suggestions.

\section{NOTES}

${ }^{1}$ See Oliver Richmond, 'Liberal Peacebuilding in Timor Leste: The Emperor's New Clothes?', International Peacekeeping, Vol.15, No.2, 2008, pp.185-200; Stein Sundstøl Erikson, 'The Liberal Peace is Neither: Peacebuilding, State Building and the Reproduction of Conflict in the Democratic Republic of Congo', International Peacekeeping, Vol.16, No.5, 2009, pp.652-66. Roger MacGinty, 'Warlords and the Liberal Peace: State-Building in Afghanistan', Conflict, Security \& Development, Vol.10, No.4, 2010, pp.577-98. Rosalind Shaw \& Pierre Hazan, Localizing Transitional Justice: Interventions and Priorities after Mass Violence, Stanford, Stanford University Press, 2010.

2 See Oliver Richmond, 'Patters of Peace', Global Society, Vol.20, No.4, 2006, pp.36794; David Chandler, 'The Responsibility to Protect: Imposing the Liberal Peace', International Peacekeeping, Vol.11, No.1, 2004, pp.59-81;

${ }^{3}$ Louise Arbour, 'Economic and Social Justice for Societies in Transition', New York University Journal of International Law and Politics, Vol.40, pp.1-27; Rosemary Nagy, 'Transitional Justice as a Global Project: Critical Reflections', Third World Quarterly, Vol.29, No.2, 2008, pp.275-89; Vanessa Pupavac, "War on the Couch: The Emotionology of the New International Security Paradigm', European Journal of Social Theory, Vol.7, No.2, 2004, pp.149-70; Rama Mani, Beyond Retribution; Seeking Justice in the Shadows of War, Malden, MA, Polity, 2002; Rosalind Shaw, Rethinking Truth and 
Reconciliation Commissions: Lessons from Sierra Leone, Washington D.C., United States Institute of Peace, 2005; Timoth Kelsall, 'Truth, Lies, Ritual: Preliminary Reflections on the Truth and Reconciliation Commission in Sierra Leone', Human Rights Quarterly, Vol.28, No.2, 2005 pp.361-91; Gearoid Millar Assessing Local Experiences of Truth-Telling in Sierra Leone: Getting to 'Why' through a Qualitative Case Study Analysis', International Journal of Transitional Justice, Vol.4, No.9, 2010, pp.477-96; Gearoid Millar, 'Between Theory and Practice: Culture and Truth-Telling in Sierra Leone', Conflict Resolution Quarterly, Vol.29, No.2, 2011, pp.177-99; Gearoid Millar, 'Ah Lef Ma Case fo God: Faith and Agency in Sierra Leone's Postwar Reconciliation', Peace and Conflict: Journal of Peace Psychology, Vol.18, No.2, 2012, pp.131-43.

${ }^{4}$ Anna Lowenhaupt Tsing, Friction: An Ethnography of Global Connection, Princeton, NJ, Princeton University Press, 2005, at xi.

${ }^{5}$ Rosalind Shaw, 'Memory Frictions: Localizing the Truth and Reconciliation Commission in Sierra Leone', International Journal of Transitional Justice, Vol.1, No.1 2007, pp.183-207.

${ }^{6}$ Tsing (see n.4 above) p.xi.

${ }^{7}$ Richard Fanthorpe, 'Neither Citizen nor Subject? 'Lumpen' Agency and the Legacy of Native Administration in Sierra Leone', Africa Affairs, Vol.100, No.400, 2001, p.364; Danny Hoffman, 'Like Beasts in the Bush: Synonyms of Childhood and Youth in Sierra Leone', Postcolonial Studies, Vol.5, No.3, 2003 p.301.

${ }^{8}$ Augustin S.J. Park, "'Other Inhuman Acts"': Forced Marriage, Girl Soldiers and the Special Court for Sierra Leone', Social and Legal Studies, Vol.15, No.3, 2006, p.327.

${ }^{9}$ Paul Richards, Fighting for the Rainforest: War, Youth \& Resources in Sierra Leone, Portsmouth, NH, Heinemann, 1996, p.6.

${ }^{10}$ Olu Gordon, 'Civil Society against the State: The Independent Press and the AFRCRUF Junta', in Ibrahim Abdullah (ed) Between Democracy and Terror: The Sierra Leone War, Dakar, Council for the Development of Social Science Research in Africa, 2004, p.180. 
${ }^{11}$ Truth and Reconciliation Commission for Sierra Leone, Witness to Truth: Report of the Sierra Leone Truth and Reconciliation Commission, Accra, Ghana, GPL Press, 2004, pp.141-43.

${ }^{12}$ Mark Freeman, Truth Commissions and Procedural Fairness, New York, NY, Cambridge University Press, 2006, p.26.

${ }^{13}$ Lyn Graybill \& Kimberly Lanegran, 'Truth, Justice, and Reconciliation in Africa: Issues and Cases', African Studies Quarterly, Vol.8, No.1, 2004, pp.1-18;

${ }^{14}$ Arie Nadler and Nurit Schnabel, 'Instrumental and Socioemotional Paths to Intergroup Reconciliation and the Needs-Based Model of Socioemotional Reconciliation', in Arie Nadler, Thomas E. Malloy,\& Jeffrey D. Fisher (eds), The Social Psychology of Intergroup Reconciliation, New York, NY, Oxford University Press, 2008, pp.37-56. ${ }^{15}$ Freeman (see n.10 above)

${ }^{16}$ Truth and Reconciliation Commission for Sierra Leone, Witness to Truth: Report of the Sierra Leone Truth and Reconciliation Commission, Accra, Ghana, GPL Press, 2004 , p.231.

${ }^{17}$ Ronald J. Fisher, 'Social-Psychological Processes in Interactive Conflict Analysis and Reconciliation', in Mohammed Abu-Nimer (ed) Reconciliation, Justice, and Coexistence, Lanham, MD, Lexington Books, 2001, p.37; For similar models of reconciliation see John Paul Lederach, Building Peace: Sustainable Reconciliation in Divided Societies, Wasington D.C., United States Institute of Peace, 1997.

${ }^{18}$ Shaw (see $n .3$ above); Kelsall (see n.3 above).

${ }^{19}$ Rosalind Shaw, 'Linking Justice with Reintegration? Ex-Combatants and the Sierra Leone Experiment', in Rosalind Shaw \& Pierre Hazan (eds) Localizing Transitional Justice: Interventions and Priorities after Mass Violence, Stanford, Stanford University Press, 2010, pp.111-132.

${ }^{20}$ See John Williamson, 'The Disarmament, Demobilization and Reintegration of Child Soldiers: Social and Psychological Transformation in Sierra Leone', Intervention, Vol.4, No.3, 2006, pp.185-205.

${ }^{21}$ William A. Schabas, 'The Sierra Leone Truth and Reconciliation Commission', in Naomi Roht-Arriaza \& Javier Mariezcurrena (eds) Transitional Justice in the Twenty- 
First Century: Beyond Truth versus Justice, Cambridge, Cambridge University Press, 2006, pp.37-38; Shaw (see n.19 above).

${ }^{22}$ William A. Schabas, 'A Synergistic Relationship: The Sierra Leone Truth and Reconciliation Commission and the Special Court for Sierra Leone', Criminal Law Forum, Vol.15, No.12 (2004), p.38.

${ }^{23}$ Sigall Horovitz, 'Transitional Criminal Justice in Sierra Leone', in Naomi Roht-Arriaza \& Javier Mariezcurrena (eds) Transitional Justice in the Twenty-First Century: Beyond Truth versus Justice, Cambridge, Cambridge University Press, 2006, p.56.

${ }^{24}$ See Millar, 2010 (n.3 above).

${ }^{25}$ Oliver P. Richmond, 'Becoming Liberal, Unbecoming Liberalism: Liberal-Local Hybridity via the Everyday as a Response to the Paradoxes of Liberal Peacebuilding', Journal of Intervention and Statebuilding, Vol.3, No.3, 2009, pp.324-44.

${ }^{26}$ Tsing (see n.4 above) p.6.

${ }^{27}$ Ibid., p.4.

${ }^{28}$ Ibid., p.224.

${ }^{29}$ Ibid., p.237, emphasis added.

30 Ibid., p.238, emphasis added.

${ }^{31}$ Shaw (see n.5 above) p.194.

32 Ibid., p.187.

${ }^{33}$ Ibid., p.193.

34 Ibid., p.207.

35 Ibid., p.207.

${ }^{36}$ Nadler \& Shnabel (see n.12 above).

${ }^{37}$ Mark Knight \& Alpaslan Özerdem, 'Guns, Camps and Cash: Disarmament, Demobilization and Reinsertion of Former Combatants in Transitions from War to Peace', Journal of Peace Research, Vol.41, No.4, 2001, pp.499-516;

38 Joanna Spear, 'From Political Economies of War to Political Economies of Peace: The Contribution of DDR after Wars of Predation', Contemporary Security Policy, Vol.27, No.1, 2006, pp.172-173. 
${ }^{39}$ Alpaslan Özerdem, 'A Re-conceptualization of Ex-combatant Reintegration: 'Social Reintegration' Appraoch', Conflict, Security \& Development, Vol.12, No.1, 2012, pp.5173.

${ }^{40}$ Shaw (see n.19 above) p.112.

${ }^{41}$ Rama Mani, Beyond Retribution: Seeking Justice in the Shadows of War, Malden, MA: Polity, p.22.

${ }^{42}$ Dominik McGoldrick, 'The Permanent International Criminal Court: An End to the Culture of Impunity?', Criminal Law Review, August, 1999, pp.627-655;

${ }^{43}$ Diane Orentlicher, 'Addressing Gross Human Rights Abuses: Punishment and Victim Compensation,' Studies in Transnational Legal Policy, Vol.26, 1994, p.434.

${ }^{44}$ William Schabas, 'The Relationship Between Truth Commissions and International Courts: The Case of Sierra Leone', Human Rights Quarterly, Vol.25, No.4, 2003, p.1037.

${ }^{45}$ Tsing (see n.4 above)

${ }^{46}$ William Easterly, The White Man's Burden: Why the Rest's Efforts to Aid the Rest Have Done So Much III and So Little Good, New York: Penguin Books Ltd., 2006. ${ }^{47}$ Mark Duffield, Development, Security and Unending War: Governing the World of People, Malden, MA: Polity, 2007.

${ }^{48}$ Ronnie D. Lipschutz, 'Reconstructing World Politics: The Emergence of Global Civil Society', Millennium - Journal of International Studies, Vol.21, No.3, 1992, pp.389-420; see also Mary Kaldor, Global Civil Society: An Answer to War, Malden, MA: Polity, 2003.

${ }^{49}$ Mauel Castells, 'The New Public Sphere: Global Civil Society, Communication networks, and Global Governance', Annals of the American Academy of Political and Social Science, Vol.616, March, 2008, p.83. 